\title{
SAKSI MAHKOTA DALAM PROSES PENYELESAIAN PERKARA (SPLITSING) DALAM PERKARA TINDAK PIDANA KORUPSI
}

Yusman.

Fakultas Hukum, Universitas Pamulang

Email : yusmanstan@gmail.com

Received: Apr 2019/Revised: Apr 2019/Accepted: Ags 2019

\begin{abstract}
Berdasarkan pasal I74 KUHAP disebutkan apabila keterangan saksi disidang disangka palsu maka hakim ketua sidang memperingatkan dengan sungguh-sungguhn kepada saksi supaya memberikan keterangan yang sebenarnya. Dan apabilan saksi tetap memberikan keterangan palsu maka akan diancam dengan dakwaan baru yaitu berupa tindak pidana kesaksian palsu sebagaimana yang diatur dalam pasal 242 KUHP. Dalam pasal 185 ayat (I) juga dijelaskan bahwa keterangan saksi sebagai alat bukti ialah apa yang saksi nyatakan dalam di sidang pengadilan. Hal ini secara tidak langsung jelas menjebak keadilan dari terdakwa. Secara implisit,keberadaan saksi mahkota juga seakan-akan membuktikan perbuatan yang ia lakukan. Dengan kesaksiannya yang benar, ia akan diancam pidana dalam posisinya sebagai terdakwa, yang tidak dapat memberi keterangan secara bebas/membela diri (terikat sumpah kala jadi saksi).
\end{abstract}

Kata Kunci : Saksi mahkota dalam proses penyelesaian perkara tindak pidana

\begin{abstract}
Under article 174 CRIMINAL PROCEDURE CODE mentioned in disidang of witnesses suspected false then the Chief Council warns solemnly sungguhn to witness so that gives the actual description. And if a witness gives false information remains it will be liable to a new indictment in the form of a criminal offence of false testimony, as provided for in article 242 of the CRIMINAL CODE. In section 185 subsection (I) also explained that the witnesses as evidence is what the witnesses stated in a court hearing. This is indirectly apparent trap the fairness of the defendant. Implicitly, the existence of a Crown witness also seem to prove that he did. With his testimony, he will be liable to criminal in his position as the defendant, who could not give information freely/self-defense (bound oath kala so witnesses).
\end{abstract}

Keywords: Crown witness in the process of settlement of the matter a criminal Offence 


\section{PENDAHULUAN}

Berdasarkan pasal 174 KUHAP disebutkan apabila keterangan saksi disidang disangka palsu maka hakim ketua sidang memperingatkan dengan sungguh-sungguhn kepada saksi supaya memberikan keterangan yang sebenarnya. Dan apabila saksi tetap memberikan keterangan palsu maka akan diancam dengan dakwaan baru yaitu berupa tindak pidana kesaksian palsu sebagaimana yang diatur dalam pasal 242 KUHP. Dalam pasal 185 ayat (I) juga dijelaskan bahwa keterangan saksi sebagai alat bukti ialah apa yang saksi nyatakan dalam di sidang pengadilan. Hal ini secara tidak langsung jelas menjebak keadilan dari terdakwa. Secara implisit,keberadaan saksi mahkota juga seakan-akan membuktikan perbuatan yang ia lakukan. Dengan kesaksiannya yang benar, ia akan diancam pidana dalam posisinya sebagai terdakwa, yang tidak dapat memberi keterangan secara bebas/membela diri(terikat sumpah kala jadi saksi). Inilah hak-hak asasi saksi mahkota yang dilanggar.

Berdasarkan teori pembuktian hukum acara pidana, keterangan yang diberikan oleh saksi di persidangan di pandang sebagai alat bukti yang penting dan utama, hampir semua pemmbuktian perkara pidana, selalu didasarkan kepada pemeriksaan keterangan saksi sekalipun keterangan saksi bukan satu-satunya alat bukti namun sekurangkurangnya di samping pembuktian dengan alat bukti yang lain, masih tetap selalu di perlukan pembuktian dengan alat bukti keterangan saksi.

Saksi yang juga seorang pelaku dalam perkara yang sama dalam ptaktek di sebut dengan saksi mahkota, seiring kita dengar berita mengenai saksi mahkota di berbagai media cetak dan eletronik, berita menyebutkan bahwa saksi mahkota adalah saksi yang juga berkedudukan sebagai tersangka.

Pemisahan perkara merupakan wewenang dari jaksa yang diatur dalam pasal 142 KUHAP, yang menyebutkan bahwa dalam hal penuntut umum menerima satu berkas perkara yang memuat beberapa tindak-tindak pidana yang dilakukan oleh beberapa orang terdakwa yang tidak termasuk dalam ketentuan pasal I4I, penuntut umum dapat melakukan penuntutan terhadap masing-masing terdakwa secara terpisah. Dan selanjutnya mengenai bunyi pasal I4I, adalah bahwa penuntut umum dapat melakukan penggabungan perkara dan membuatnya dalam satu dakwaan,apabila pada waktu yang sama atau hampir bersamaan ia menerima beberapa berkas perkara dalam hal : 
I. Beberapa tindak pidana yang dilakukan oleh seorang yang sama dan kepentingan pemeriksaan tidak menjadikan halangan terhadap penggabungannya;

2. Beberapa tindak pidana yang bersangkut paut dengan yang lain;

3. Beberapa tindak pidana yang tidak bersangkut paut satu dengan yang lain,akantetapi yang satu dengan yang lain itu ada hubungannya, yang dalam hal ini

4. penggabungan tersebut perlu bagi kepentingan pemeriksaan.

Pemecahan penuntutan perkara (splitsing) seperti yang dimaksud dalam ketentuan pasal 142 KUHAP biasanya splitsing dilakukan dengan membuat berkas perkara, dalam hal yang demikian perlu dilakukan pemeriksaan baru, baik terhadap terdakwa maupun saksi. Mungkin akan menimbulkan permasalahan dalam praktek,ialah sehubungan dengan masalah apakah penuntut umum berwenang membuat berkas perkara baru sehubungan dengan splitsing itu. Dalam hubungan ini penyidik dapat melaksanakan splitsing, atas petunjuk penuntut umum.Adapun yang menjadi dasar pemikirannya adalah : jika masalah splitsing ini masih dalam tingkat persiapan tindakan penuntutan (pra penuntutan), dan belum sampai pada tingkat penyidangan perkara di pengadilan. Oleh sebab itu dalam hal penuntut umum menerima hasil penyelidikan, sekaligus meneliti serta mempelajari perkara yang perlu atau tidaknya dilakukan splitsing, dan jika ia berpendapat bahwa perkara tersebut perlu untuk dilakukan splitsing, dalam waktu tujuh hari hendaknya wajib memberitahu kepada penyidik untuk dilengkapi dan disempurnakan dengan diberikan beberapa petunjuk seperlunya dan penyidik dalam waktu empat belas hari sejak tanggal penerimaan berkas perkara yang telah displitsing.

Alat bukti berupa Keterangan Terdakwa diantaranya juga menjadi salah satu faktor penting untuk menemukan petunjuk guna membuat keyakinan hakim. Dalam alat bukti berupa petunjuk salah satunya adalah memperhatikan singkronisasi antara keterangan saksi saksi yang dihadirkan guna membuat terang suatu tindak pidana dan juga keterangan dari terdakwa yang didakwakan melakukan tindak pidana tersebut.

Keterangan terdakwa memiliki aspek aspek yang erat kaitannya dengan Hak Asasi Manusia, dimana dalam hal ini keterangan Terdakwa akan dikaitkan dengan Right to remain silence dan Non Self Incrimination selaku asas penting yang keberlakuannya sudah diakui secara umum. Selain itu keterangan terdakwa juga berkaitan dengan 'saksi mahkota' dalam hal terjadinya suatu tindak pidana yang berkaitan dengan 
penyertaan tindak pidana. Saksi mahkota merupakan hal yang masih diperdebatkan eksistensinya sampai saat ini, meskipun sudah ada putusan Mahkamah Agung yang mengatakan bahwa Saksi Mahkota diperbolehkan dalam membuat terang suatu tindak pidana, namun ada juga Putusan Mahkamah Agung lainnya yang menolak dihadirkannya saksi Mahkota dalam suatu perkara pidana.

Nilai pembuktian dari keterangan terdakwa juga bergantung kepada sistem hukum yang dianut oleh suatu negara dan tentunya berbeda satu sama lainnya, dan untuk itu pada makalah ini akan dijabarkan secara singkat mengenai kedudukan keterangan terdakwa dalam pembuktian suatu tindak pidana dari beberapa negara.

Jika mengacu pada ketentuan Pasal 66 KUHAP dan Article I4 point 3 point $g$ ICCPR yang mengatakan bahwa Terdakwa tidak boleh dipaksa untuk mengaku bersalah, maka seorang terdakwa tidak dibebankan suatu beban pembuktian dan tidak dapat dipaksa untuk bersaksi atas dirinya sendiri atau dipaksa mengaku bersalah (asas non-self incrimination), bahkan dalam Pasal 175 KUHAP pun seorang terdakwa memiliki hak ingkar (right to remain silent), yaitu untuk menolak menjawab pertanyaan yang diajukan pada dirinya di dalam persidangan, maka dengan demikian rasanya mustahil untuk menghadirkan seorang yang secara bersama-sama bertindak sebagai terdakwa dalam acara pemeriksaan di suatu sidang pengadilan. Hal tersebut pun didukung oleh ketentuan dalam Pasal i68 huruf $b$ KUHAP yang menyatakan bahwa seseorang yang bertindak bersama-sama sebagai terdakwa dapat mengundurkan diri sebagai saksi.

Ditinjau dari perspektif sistem peradilan pidana maka perihal pembuktian merupakan hal yang sangat determinan bagi setiap pihak yang terlibat secara langsung dalam proses pemeriksaan perkara pidana, khususnya dalam hal menilai terbukti atau tidak terbuktinya kesalahan yang didakwakan kepada terdakwa. Dalam rangka mendukung tugasnya sebagai pihak yang memiliki beban untuk membuktikan kesalahan terdakwa.Dalam kapasitasnya sebagai pihak yang memiliki kewenangan untuk melakukan pemeriksaan pada tingkatan pengadilan maka perihal pembuktian merupakan faktor yang juga sangat menentukan bagi hakim dalam mendukung pembentukan faktor keyakinan hakim. Hal tersebut sebagaimana yang tercantum dalam ketentuan Pasal 183 KUHAP yang pada pokoknya menjelaskan bahwa hakim dalam menjatuhkan pidana kepada terdakwa harus didasarkan pada minimal dua alat bukti yang sah dan keyakinan hakim yang terbentuk didasarkan pada alat bukti yang sah 
tersebut.IKetentuan ini adalah untuk menjamin tegaknya kebenaran, keadilan, dan kepastian hukum bagi seseorang. Oleh karena itu, apabila ditinjau dari perspektif yuridis maka dalam perihal pembuktian tersebut tentunya harus berisi ketentuan tentang jenis alat bukti dan ketentuan tentang tata cara pembuktian yang dilakukan secara benar dan tidak boleh dilakukan secara sewenang-wenang dengan melanggar hak asasi terdakwa.2

Seringkali dalam berbagai sidang pembuktian perkara pidana, muncul alat bukti yang disebut dengan istilah saksi mahkota.Pada dasarnya, istilah saksi mahkota tidak disebutkan secara tegas dalam KUHAP. Penggunaan alat bukti saksi mahkota hanya dapat dilihat dalam perkara pidana yang berbentuk penyertaan, dan terhadap perkara pidana tersebut telah dilakukan pemisahan (splitsing) sejak proses pemeriksaan pendahuluan di tingkat penyidikan. Selain itu, munculnya dan digunakannya saksi mahkota dalam perkara pidana yang dilakukan pemisahan tersebut didasarkan pada alasan karena kurangnya alat bukti yang akan diajukan oleh penuntut umum.

\section{PERMASALAHAN}

Berdasarkan latar belakang yang diuraikan di atas, maka penulis merumuskan masalah sebagai berikut yakni, Apa peranan saksi mahkota dalam perkara tindak pidana?

\section{METODOLOGI PENELITIAN}

Metode penelitian menggunakan penelitian hukum normatif bersifat deskriftif, dengan mengunakan sumber data primer dan data sekunder sebagai bahan penulisan. Sumber Data Primer Sumber data primer merupakan sumber data yang menunjang dalam proses penulisan skripsi hukum ini. .Sumber Data Sekunder Sumber data sekunder merupakan sumber data dari hasil studi pustaka yang dilakukan oleh penulis dan dijadikan sebagai data pokok yang digunakan penulis sebagai analisa yuridis yang mendukung sumber data primer dalam penulisan skripsi ini, yang terdiri dari. Bahan hukum Primer Kitab Undang-Undang Hukum Pidana Kitab Undang-Undang Hukum Acara Pidana Bahan Hukum Sekunder Bahan hukum merupakan bahan hukum yang memberikan

1Martiman Prodjohamidjojo, Komentar Atas KUHAP : Kitab Undang-Undang Hukum Acara Pidana, Pradnya Paramita, Jakarta, 1990, hlm. 133

2M. Yahya Harahap, Pembahasan Permasalahan Dan Penerapan KUHAP : Pemeriksaan Sidang Pengadilan, Banding, Kasasi Dan Peninjauan Kembali, Sinar Grafika, Jakarta, 2003, hlm. 252 
penjelasan mengenai bahan hukum primer, seperti Undang-Undang, hasil penelitian, pendapat ahli dan lain-lain. Bahan Hukum Tertier Bahan hukum tertier merupakan bahan hukum yang memberikan petunjuk maupun penjelasan terhadap hukum primer dan hukum sekunder, seperti.Kamus, ensiklopedi.

\section{PEMBAHASAN}

\section{Tinjauan Umum Tentang Saksi.}

Saksi adalah orang yang menerangkan apa yang ia lihat, apa yang ia dengar dan apa yang ia alami dengan menyebutkan dasar pengetahuannya, tidak semua keterangan saksi sebagai alat bukti mempunyai kekuatan pembuktian. Keterangan saksi sebagai alat bukti yang mempunyai kekuatan pembuktian ialah keterangan saksi yang ia dengar sendiri, saksi lihat sendiri, dan saksi alami sendiri, dan keterangan saksi harus dapat menyebut alasan dari pengetahuannya. Pendapat atau rekaan yang diperoleh dari hasil pemikiran, bukan merupakan keterangan saksi. sehingga setiap keterangan saksi diluar apa yang didengarnya sendiri, diluar peristiwa pidana tidak dapat dijadikan dan dinilai sebagai alat bukti, begitu pula dengan keterangan saksi yang diperoleh dari orang lain.

Keterangan saksi mengenai suatu peristiwa pidana dapat dinilai kebenarannya dengan memperhatikan:

I. Persesuaian antara keterangan saksi satu dengan saksi lain

2. Persesuaian antara keterangan saksi dengan alat bukti lain

3. Alasan yang mungkin dipergunakan oleh saksi untuk memberikan keterangan

4. Cara hidup dan kesusilaan saksi serta segala sesuatu yang pada umumnya dapat mempengaruhi dapat tidaknya keterangan itu dipercaya.

\section{Batas minimum pembuktian keterangan saksi}

Keterangan saksi agar dapat dianggap cukup membuktikan kesalahan terdakwa harus dipenuhi sekurang-kurangnya dengan dua alat bukti. Keterangan seorang saksi saja, baru dinilai suatu alat bukti yang harus ditambah dan dicukupi dengan alat bukti lain. Jadi, bertitik tolak dari ketentuan Pasal I85 ayat (2) KUHAP, keterangan seorang saksi saja belum dapat dianggap sebagai alat bukti yang cukup untuk membuktikan kesalahan terdakwa, atau unus testis nullus testis. Jika alat bukti yang dikemukakan penuntut umum hanya terdiri dari seorang saksi saja tanpa ditambah dengan keterangan saksi yang lain atau alat bukti yang lain, 
kesaksian seorang saksi saja tidak dapat dinilai sebagai alat bukti yang cukup untuk membuktikan kesalahan terdakwa sehubungan dengan tindak pidana yang didakwakan kepadanya. Walaupun seandainya keterangan seorang saksi saja sedemikian rupa jelasnya, tetapi terdakwa tetap mangkir serta kesaksian tunggal itu tidak ditambah dan dicukupi dengan alat bukti lain, kesaksian seorang saksi saja harus dinyatakan tidak mempunyai nilai kekuatan pembuktian atas alasan unnus testis nullus testis.

Dalam suatu tindak pidana terdapat beberapa pelaku atau pelaku lebih dari satu orang (terdapat unsur penyertaan (deelneming), menurut M. Yahya Harahap, langkah yang biasanya ditempuh oleh penyidik dan penuntut umum agar keterangan seorang terdakwa dapat dipergunakan sebagai alat bukti yang sah terhadap terdakwa lainnya yaitu dengan cara menempatkan terdakwa yang lain itu dalam kedudukan sebagai saksi.3 Dengan demikian akan memenuhi prinsip minimum pembuktian. Tidak demikian halnya jika terdakwa memberikan keterangan yang mengakui kesalahan yang didakwakan kepadanya. Kondisi seperti ini seorang saksi sudah cukup membuktikan kesalahan terdakwa, karena disamping keterangan seorang saksi saja itu, telah dicukupi dengan alat bukti keterangan terdakwa. Keterangan seorang saksi saja mempunyai nilai pembuktian kesalahan terdakwa, harus dilengkapi atau dicukupi dengan salah satu alat bukti yang lain baik berupa keterangan ahli, surat, petunjuk maupun dengan keterangan terdakwa. Keterangan unus testis nullus testis sebagaimana pasal 185 ayat (2) KUHAP hanya berlaku bagi pemeriksaan biasa dan pemeriksaan singkat, tidak berlaku bagi pemeriksaan singkat, tidak berlaku bagi pemeriksaan cepat, hal ini dapat disimpulkan dari Penjelasan Pasal 184 KUHAP yaitu : "Dalam acara pemeriksaan cepat didukung suatu alat bukti yang sah. Yang artinya, suatu saksi, suatu keterangan ahli, suatu surat, suatu petunjuk, atau keterangan terdakwa disertai keyakinan hakim cukup sebagai alat bukti untuk mempidanakan terdakwa. Acara pemeriksaan cepat ini terbagi menjadi dua, yaitu pemeriksaan ringan dan acara pemeriksaan perkara pelanggaran lalu lintas jalan.4 Apabila syarat-syarat di atas telah dipenuhi, maka keterangan saksi tersebut menjadi alat bukti yang sah dan terhadapnya melekat nilai kekuatan pembuktian. Pada dasarnya, penilaian terhadap keterangan yang diberikan oleh seorang saksi adalah bebas, artinya seorang hakim bebas untuk menilai atau mengesampingkan isi keterangan seorang saksi yang diberikan di persidangan. Menurut Hari Sasangka dan Lily Rosita, 
keadaan tersebut ada benarnya karena seringkali seorang saksi di dalam memberikan keterangan dilandasi suatu motivasi tertentu.5

Mengenai kekuatan pembuktian keterangan yang diberikan oleh saksi mahkota sebagai alat bukti keterangan saksi adalah pertama, keterangan yang diberikan oleh saksi mahkota mempunyai nilai kekuatan pembuktian bebas, yaitu tidak mempunyai nilai kekuatan pembuktian yang sempurna dan juga tidak memiliki kekuatan pembuktian yang menentukan atau mengikat; kedua, nilai kekuatan pembuktiannya tergantung pada penilaian hakim yang dimaksud dengan artian bahwasanya hakm disini bebas untuk menilai kesempurnaan dan kebenaran dari saksi mahkota dalam persidangan pidana. Selanjutnya akan dibahas mengenai konsep saksi mahkota di Indonesia berdasarkan doktrin dan praktik dengan memperbandingkan juga konsep saksi mahkota yang terdapat di Negara lain.

\section{Kedudukan Saksi dalam Peradilan Pidana.}

Dalam upaya membuktikan terjadinya suatu tindak pidana, peran saksi-saksi sangat penting. Keterangan beberapa orang saksi bisa meyakinkan hakim bahwa suatu tindak pidana benar-benar terjadi seperti dakwaan jaksa, atau sebaliknya menguatkan alibi terdakwa. Mengingat urgensi yang demikian, Kitab Undang-Undang Hukum Acara Pidana (KUHAP) menjadikan keterangan saksi sebagai salah satu alat bukti. Selama puluhan tahun, sejak UU No. 8 Tahun 198I (KUHAP) berlaku, saksi diartikan sebagai orang yang dapat memberikan keterangan guna kepentingan penyidikan, penuntutan dan peradilan tentang suatu perkara pidana yang ia dengar sendiri, ia lihat sendiri, dan ia alami sendiri. Pasal I angka 27 KUHAP menjelaskan keterangan saksi adalah salah satu alat bukti dalam perkara pidana yang berupa keterangan dari saksi mengenai suatu peristiwa pidana yang ia dengar sendiri, ia lihat sendiri dan ia alami sendiri dengan menyebut alasan dari pengetahuannya itu. Dalam buku Pembahasan Permasalahan dan Penerapan KUHAP: Pemeriksaan Sidang Pengadilan, Banding, Kasasi, dan Peninjauan Kembali tidak semua keterangan saksi mempunyai nilai sebagai alat bukti. Keterangan yang mempunyai nilai adalah keterangan yang sesuai dengan apa yang dijelaskan pasal I angka 27 KUHAP tersebut. Bahkan Harahap menerangkan lebih lanjut bahwa keterangan yang diberikan di luar pendengaran, penglihatan, atau pengalaman sendiri mengenai suatu peristiwa pidana "tidak dapat dijadikan dan dinilai sebagai alat bukti". 
Dengan merujuk pada adagium 'testimonium de auditu' Harahap menyatakan keterangan saksi yang ia peroleh sebagai hasil pendengaran orang lain tidak mempunyai nilai sebagai alat bukti. Definisi ini telah dianut polisi, jaksa, hakim, dan pengacara selama puluhan tahun. Doktrin dan literatur hukum acara pidana juga nyaris tak ada yang mengkritisi makna saksi dalam KUHAP. Menurut Mahkamah Konstitusi, pengertian saksi menguntungkan dalam pasal 65 KUHAP tidak dapat ditafsirkan secara sempit hanya dengan mengacu pada pasal I angka 26 dan angka 27 KUHAP. Pengertian saksi dalam pasal tersebut membatasi bahkan menghilangkan kesempatan bagi tersangka atau terdakwa untuk mengajukan saksi yang menguntungkan baginya, karena frase "ia dengar sendiri, ia lihat sendiri dan ia alami sendiri" mensyaratkan bahwa hanya saksi yang mendengar sendiri, melihat sendiri, dan mengalami sendiri suatu perbuatan dapat diajukan sebagai saksi menguntungkan bagi tersangka/terdakwa.

Dalam khasanah pengetahuan hukum Indonesia, terdapat berbagai definisi atau pengertian dari saksi, baik itu dalam KUHAP, peraturan perundang-undangan lainnya, maupun pendapat para pakar hukum. KUHAP sebagai ketentuan pokok yang mengatur hukum acara pidana yang bersifat umum (lex generalis) berlaku bagi semua tindak pidana kecuali yang mengaturnya secara menyimpang/khusus (lex specialis) dalam undang-undang khusus, telah memberikan definisi atau pengertian "saksi" dalam Pasal I butir 26, yaitu: "Orang yang dapat memberikan keterangan guna kepentingan penyidikan, penuntutan, dan peradilan tentang suatu perkara pidana yang ia dengar sendiri, ia lihat sendiri dan ia alami sendiri." Definisi saksi di atas cukup luas atau umum, sehingga yang termasuk dalam pengertian saksi bisa orang yang menjadi korban, pelapor, pengadu, maupun orang lain yang dapat memberikan keterangan tentang suatu perkara pidana baik di tingkat penyidikan, penuntutan, maupun di muka sidang pengadilan.Kebanyakan undang-undang pidana khusus yang dibuat sesudah berlakunya KUHAP tidak memberikan definisi atau pengertian saksi secara khusus, artinya, saksi yang dimaksud dalam undang-undang tersebut mengacu pada pengertian saksi yang diatur dalam KUHAP. Memang ada beberapa perundang-undangan yang memberikan definisi saksi, walaupun tidak ada perbedaan secara mendasar dengan yang diatur dalam KUHAP. Pengertian saksi yang lebih luas dapat diketemukan dalam Peraturan Pemerintah No. 2 tahun 2002 tentang Tata Cara Perlindungan Terhadap Korban dan Saksi Pelanggaran HAM. Peraturan pelaksanaan UU No. 26 tahun 2000 tentang Pengadilan HAM, yang memberikan definisi saksi sebagai:"orang yang dapat memberikan 
keterangan guna kepentingan penyelidikan, penyidikan, penuntutan, dan atau pemeriksaan di sidang pengadilan tentang perkara pelanggaran hak asasi manusia yang berat yang ia dengar sendiri, lihat sendiri, dan alami sendiri, yang memerlukan perlindungan fisik dan mental dari ancaman, gangguan, teror, dan kekerasan dari pihak manapun" Perbedaan dengan definisi yang diberikan KUHAP adalah diperluasnya pengertian meliputi juga orang yang memberikan keterangan untuk kepentingan penyelidikan, di samping penyidikan, penuntutan, dan pemeriksaan sidang pengadilan. Karena PP ini mengatur tentang perlindungan terhadap saksi dan korban, maka pengertian saksi di sini juga dipersempit hanya saksi yang memerlukan perlindungan fisik dan mental dari ancaman, gangguan, teror, dan kekerasan dari pihak manapun. Peraturan Pemerintah No. 57 Tahun 2003 tentang Tata Cara Perlindungan Khusus bagi Pelapor dan Saksi Tindak Pidana Pencucian Uang sebagai peraturan pelaksanaan dari Undang-undang Nomor 15 Tahun 2002 tentang Tindak Pidana Pencucian Uang sebagaimana telah diubah dengan Undang-undang Nomor 25 Tahun 2003, dalam Pasal I butir 3 memberikan pengertian saksi sebagai: "orang yang dapat memberikan keterangan guna kepentingan penyidikan, penuntutan, dan peradilan tentang suatu perkara pidana pencucian uang yang didengar sendiri, dilihat sendiri, dan dialami sendiri." Definisi ini sama dengan KUHAP, hanya ada pengkhususan untuk pemberian keterangan pada perkara pidana pencucian uang. Berbeda dengan KUHAP yang tidak memberikan pengertian khusus tentang "pelapor" (sehingga masuk dalam pengertian saksi), Undang-Undang Pencucian Uang dan PPnya di atas ada membedakan secara tegas antara saksi dengan pelapor. Pasal I butir 2 PP No. 57 tahun 2003 menyebutkan: "Pelapor adalah setiap orang yang: a. karena kewajibannya berdasarkan peraturan perundangundangan menyampaikan laporan kepada PPATK tentang transaksi keuangan mencurigakan atau transaksi keuangan yang dilakukan secara tunai sebagaimana dimaksud dalam Undang-undang; atau b. secara sukarela melaporkan kepada penyidik tentang adanya dugaan terjadinya tindak pidana pencucian uang sebagaimana dimaksud dalam Undangundang".Perlindungan hukum dalam undang-undang ini lebih ditujukan terhadap pelapor sebagaiman di atas. Ketentuan yang demikian adalah janggal, karena justru saksi yang memberikan kesaksian di muka penyidik atau hakim tidak diatur secara eksplisit perlindungannya. Undang-undang No. 13 tahun 2006 tentang Perlindungan Saksi dan Korban sebagai produk hukum terbaru yang secara khusus mengatur tentang perlindungan saksi dan korban, memberikan pengertian saksi dan korban, akan tetapi tidak memberikan pengertian tentang pelapor. 
Pengertian Saksi adalah (Pasal I butir I): "orang yang dapat memberikan keterangan guna kepentingan penyelidikan, penyidikan, penuntutan, dan pemeriksaan di sidang pengadilan tentang suatu perkara pidana yang ia dengar sendiri, ia lihat sendiri, dan/atau ia alami sendiri)." Sedangkan Korban adalah (Pasal I butir 2): "seseorang yang mengalami penderitaan fisik, mental, dan/atau kerugian ekonomi yang diakibatkan oleh suatu tindak pidana". definisi saksi yang dipakai oleh UU PSK, mengikuti (cakupan) definisi yang dibuat dalam Peraturan Pemerintah No. 2 Tahun 2002 tentang Tata Cara Perlindungan Terhadap Korban dan Saksi Pelanggaran HAM. Peraturan Pemerintah No. 24 Tahun 2003 tentang Tata Cara Perlindungan Terhadap Saksi, Penyidik, Penuntut Umum, dan Hakim dalam Perkara Tindak Pidana Terorisme, meliputi juga yang memberikan keterangan pada (mulai) tahap penyelidikan, sedangkan menurut KUHAP, hanya dimulai pada tahap penyidikan. Mengingat UU PSK ini merupakan undang-undang yang bersifat umum (The Umbrella Act.) yang mengatur tentang saksi dan korban, maka harus dipahami bahwa ketentuan dalam undang-undang ini berlaku untuk saksi dan korban semua tindak pidana, walaupun dalam peraturan peralihan Pasal 44 dikatakan bahwa pada saat Undang-undang ini diundangkan, peraturan perundang-undangan yang mengatur mengenai perlindungan terhadap Saksi dan/atau Korban dinyatakan tetap berlaku sepanjang tidak bertentangan dengan Undang-Undang ini.Dalam konteks sistem peradilan pidana, secara yuridis, saksi adalah "orang yang dapat memberikan keterangan guna kepentingan penyidikan, penuntutan dan peradilan tentang suatu perkara pidana yang ia dengar sendiri, ia lihat sendiri dan ia alami sendiri".6 Sedangkan secara sosiologis, pengertian saksi sering dipahami meliputi juga "ahli", maka populer istilah "saksi ahli". Akan tetapi secara yuridis, antara "saksi" dan "(saksi) ahli" adalah berbeda, sehingga di dalam Pasal 184 KUHAP dibedakan antara "keterangan saksi" dan "keterangan ahli" sebagai dua alat bukti yang berbeda."Keterangan saksi", menurut Pasal i butir 27 KUHAP, adalah: "salah satu alat bukti dalam perkara pidana yang berupa keterangan dari saksi mengenai suatu peristiwa pidana yang ia dengar sendiri, ia lihat sendiri dan ia alami sendiri dengan menyebut alasan dari pengetahuannya itu". Sedangkan "Keterangan ahli" menurut Pasal I butir 28 KUHAP adalah: "keterangan yang diberikan oleh seorang yang memiliki keahlian khusus tentang hal yang diperlukan untuk membuat terang suatu perkara pidana guna

6 Iqbal, Muhamad. "IMPLEMENTASI EFEKTIFITAS ASAS OPORTUNITAS DI INDONESIA DENGAN LANDASAN KEPENTINGAN UMUM." Jurnal Surya Kencana Satu: Dinamika Masalah Hukum dan Keadilan 9.1 (2018). 
kepentingan pemeriksaan". Dari rumusan di atas diketahui bahwa saksi bisa orang yang melihat, mendengar, atau orang yang mengalami tindak tindak pidana. Jadi salah satu saksi yang sangat potensial adalah korban tindak pidana itu. Sedangkan orang yang mendengar dari orang yang mendengar tindak pidana atau yang populer dengan adagium testimonium de auditu tidak dapat menjadi saksi dalam perkara pidana.

Dalam praktek hukum acara pidana, saksi dibedakan menjadi beberapa macam, yaitu:
a. Saksi korban;
b. Saksi mahkota;
c. Saksi verbalisan;
d. Saksi a charge;7

\section{Kedudukan dan Peranan Saksi dalam Sistem Peradilan Pidana}

Sebagaimana diketahui, bahwa jumlah personil penyelidik dan penyidik sangatlah terbatas, dibandingkan dengan besarnya jumlah penduduk Indonesia dan luasnya wilayah negara Republik Indonesia, sehingg tidak mungkin dapat meng-cover setiap tindak pidana yang terjadi di masyarakat. Karena itu, bantuan anggota masyarakat (sebagai saksi) untuk melaporkan dan atau mengadukan tentang terjadinya tindak pidana sangat membantu penyelidik dan penyidik dalam penegakan hukum terhadap pelaku tindak pidana itu. Jadi, saksi (pelapor dan/atau korban) sudah memiliki kontribusi penting sejak dimulainya proses penanganan perkara pidana (penyelidikan), demikian juga dalam proses selanjutnya, yaitu pemeriksaan di tingkat penyidikan maupun pembuktian di muka sidang pengadilan. Banyak kasus yang "nasib"nya ditentukan oleh ada tidaknya saksi, walaupun saksi bukan satu-satunya alat bukti. Dalam tahap penyelidikan sampai pembuktian di muka sidang pengadilan, kedudukan saksi sangatlah penting, bahkan dalam praktek sering menjadi faktor penentu dan keberhasilan dalam pengungkapan suatu kasus, karena bisa memberikan "keterangan saksi" yang ditempatkan menjadi alat bukti pertama dari lima alat bukti yang sah sebagaimana diatur dalam Pasal i84 KUHAP. Bahkan seorang praktisi hukum,

Muhammad Yusuf, secara ekstrim mengatakan, bahwa tanpa kehadiran dan peran dari saksi, dapat dipastikan suatu kasus akan menjadi durk number mengingat dalam sistem hukum yang berlaku di Indonesia yang

7Saksi A Chargeadalah saksi dalam perkara pidana yang dipilih dan diajukan oleh penuntut umum, dikarenakan kesaksiannya yang memberatkan terdakwa." Darwan Prinst. 2002. Hukum Acara Pidana Dalam Praktik. Jakarta: Djambatan. hal. 142. 
menjadi referensi dari penegak hukum adalah testimony yang hanya dapat diperoleh dari saksi atau ahli. Berbeda dengan sistem hukum yang berlaku di Amerika yang lebih mengedepankan barang bukti.8

\section{Kekuatan Kesaksian Dalam Hukum Pidana}

Berkaitan dengan pembahasan persidangan menggunakan telekonferensi yang dilakukan pada tahap proses pemeriksaan saksi yang bertujuan untuk membuktikan unsur-unsur kesalahan yang telah didakwakan oleh Penuntut Umum, maka pertama-tama penulis perlu membahas tentang arti pembuktian.Pembuktian memegang peranan yang sangat penting dalam proses pemeriksaan perkara di sidang pengadilan, karena melalui pembuktian nasib terdakwa ditentukan bersalah atau tidak bersalah. Apabila hasil pembuktian yang didukung dengan alat-alat bukti (sesuai dengan Pasal I84 KUHAP) "tidak cukup" membuktikan kesalahan yang didakwakan kepada terdakwa , maka terdakwa "dibebaskan” dari hukuman. Sebaliknya, kalau kesalahan terdakwa dapat dibuktikan dengan alat-alat bukti dan didukung oleh keyakinan hakim, maka terdakwa dinyatakan terbukti "bersalah". Oleh karena itu hakim dalam melakukan pemeriksaan perkara di persidangan dituntut bersikap cermat, seksama, dan teliti dalam mempertimbangkan dan menilai nilai pembuktian. Disamping itu hakim harus meneliti sampai dimana "kekuatan pembuktian (bewijs kracht)" dari setiap alat bukti tersebut dapat dipergunakan untuk membuktikan kebenaran unsur dari pasal yang didakwakan. Dengan demikian proses yang dilakukan oleh hakim dalam meneliti kekuatan pembuktian dari setiap alat bukti yang diajukan di persidangan merupakan perwujudan dari asas pemeriksaan secara cermat, seksama, dan teliti demi mencari dan mendapatkan kebenaran materiil sebagai tujuan dari hukum pidana.

Adapun yang dimaksud dengan membuktikan adalah memberikan dasar-dasar yang cukup kepada Hakim dalam pemeriksaan suatu perkara agar dapat memberikan kepastian tentang kebenaran peristiwa yang diajukan. Jadi pembuktian secara yuridis adalah mengajukan fakta-fakta menurut hukum yang cukup untuk memberikan kepastian tentang kebenaran peristiwa yang diajukan.

8Muhammad Yusuf. Urgensi Perlunya Memberikan Perlindungan Terhadap Saksi. (Tulisan pakar) http://Parlemen net. 30/03/04. page 1 . 


\section{KESIMPULAN}

Pembuktian merupakan ketentuan yang mengatur alat-alat bukti yang dibenarkan oleh undang-undang yang boleh dipergunakan hakim dalam membuktikan kesalahan yang didakwakan kepada terdakwa, dari uraian tersebut dapat disimpulkan pembuktian dalam hukum acara pidana yaitu : a. Ketentuan yang membatasi sidang pengadilan dalam usaha mencari dan mendapatkan kebenaran materiil. baik hakim, penuntut umum, terdakawa, atau penasihat umum semua terikat pada ketentuan tata cara dan penilaian alat bukti yang ditentukan oleh undang-undang. b.Majelis hakim dalam menilai dan mempertimbangkan kekuatan pembuktian selama pemeriksaan perkara di persidangan dituntut bersikap cermat, seksama, dan teliti yang senantiasa berdasarkan serta mengutamakan alat bukti dan menghubungkannya dengan barang bukti. c. Dalam melakukan pemeriksaan hakim harus mematuhi segala ketentuanketentuan dan asas-asas yang terdapat dalam hukum acara yang berlaku dengan tanpa mengkaitkan perasaan dan pendapat hakim yang subyektif.

\section{SARAN}

Dalam pemeriksaan tersangka atau terdakwa berhak memberikan keterangan secara bebas kepada penyidik atau hakim sebagaimana pasal 52 KUHAP. Oleh karena itu wajib dicegah adanya paksaan atau tekanan terhadap tersangka atau terdakwa, hal itu dimaksudkan agar tersangka atau terdakwa dijauhkan dari rasa takut sehingga pemeriksaan dapat mencapai hasil yang tidak menyimpang dari sebenarnya.

\section{DAFTAR PUSTAKA}

Lilik Mulyadi, Putusan Hakim Dalam Hukum Acara Pidana : Teori, Praktik, Teknik Penyusunan dan Permasalahannya, Citra Aditya Bakti, Bandung 2007

Martiman Prodjohamidjojo, Komentar Atas KUHAP : Kitab Undang-Undang Hukum Acara Pidana, Pradnya Paramita, Jakarta, 1990,

M. Yahya Harahap, Pembahasan Permasalahan Dan Penerapan KUHAP : Pemeriksaan Sidang Pengadilan, Banding, Kasasi Dan Peninjauan Kembali, Sinar Grafika,

Suryono Sutarto, Hukum Pidana Jilid I, Badan Penerbit UNDIP, Semarang

Barda Nawawi Arief, Kebijakan Hukum Pidana, Citra Aditya Bhakti, Bandung, 1996,

Barda Nawawi Arief, Bunga Rampai Kebijakan Hukum Pidana Perkembangan Penyusunan Konsep KUHP Baru, cetakan ke- I, Kencana Prenada Media Group, Jakarta, 2008, 
Indriyanto Seno Aji, Prospek Perlindungan Saksi Dan Korban Dalam System Hukum Pidana Indonesia, Universitas Indonesia, Depok, 2007

Bambang Poernomo, Asas-asas Hukum Pidana, Ghalia Indonesia, Jakarta, 1985,

Jan Remmelink, Hukum Pidana, Gramedia Pustaka Utama, Jakarta, 2003, Kitab Undang - Undang Hukum Pidana (KUHP)

Kitab Undang- Undang Hukum Acara Pidana (KUHAP) 
